\title{
PEMBELAJARAN JARAK JAUH PADA KEPANITERAAN KLINIS PROGRAM STUDI PROFESI DOKTER DI RUMAH SAKIT PENDIDIKAN
}

\author{
Santi Anugrahsari ${ }^{1}$ \\ ${ }^{1}$ Dokter Pendidik Klinis Departemen Mata RSUD Koja / FKIK Universitas Kristen Krida Wacana, Mahasiswa \\ Program Doktor Manajemen Pendidikan Universitas Negeri Jakarta \\ Email : santianugrah@gmail.com
}

\begin{abstract}
Introduction: It is not easy to regulate the clerkship system for medical professional education clinics when continuing to the hospital during the pandemic (Covid-19) so that students can acquire knowledge and skills according to predetermined competencies. Objective: Describe Distance Learning (PJJ) of Clinical clerkship students (coass) in teaching hospitals during the pandemic.

Methods: A descriptive study of Clinical Clerkship students who carried out online activities during the pandemic period at the Teaching Hospital.

Results: There were 51 respondents from clinical clerkship education participants, as many as $84.31 \%$ of respondents graduated from academic education in 2019-2020, just carried out the 1-2 rotation stage $47.05 \%$, long waiting for the pandemic 5-7 months experienced by $56.86 \%$ of respondents, there were more students who did not experience difficulties in accessing the internet, and simply adapting to do PJJ. Less than $50 \%$ of the learning time provided is appropriate. Students are satisfied to receive learning time per day, student communication with clinical teaching lecturers is classified as useful, and scheduling of learning with clinical doctors is relatively easy. Respondents answered PJJ quite effectively, as much as 56.86\%.

Conclusion: The most prominent problem is the fulfillment of clinical clerkship competence in patients' interactions in teaching hospitals due to the pandemic. However, more than that, various efforts have been made by institutions that provide clinical medical education.
\end{abstract}

Keywords: Clinical Clerkship - Teaching Hospital - Distance Learning - Doctor's Professional Study Program

\begin{abstract}
ABSTRAK
Pendahuluan : Hal yang tidak mudah dalam mengatur sistem kegiatan kepaniteraan klinik pendidikan profesi dokter pada saat melanjutkan stase di rumah sakit selama masa pandemi (Covid-19) sehingga peserta didik dapat memperoleh pengetahuan dan keterampilan sesuai dengan kompetensi yang telah ditetapkan. Tujuan : Menggambarkan Pembelajaran Jarak Jauh (PJJ) peserta didik kepaniteraan muda (coass) di Rumah Sakit Pendidikan selama pandemi.

Metode : Penelitian deskriptif terhadap peserta didik kepaniteraan muda yang melakukan kegiatan daring selama masa pandemi di Rumah Sakit Pendidikan.

Hasil : Terdapat 51 responden dari peserta pendidikan kepaniteraan klinis, sebanyak $84,31 \%$ responden lulus dari pendidikan akademik di tahun 2019-2020, baru menjalankan stase 1-2 rotasi 47,05\%, lama menunggu pandemi 5-7 bulan di alami oleh $56,86 \%$ responden, lebih banyak peserta didik tidak mengalami kesulitan akses internet, dan beradaptasi cukup melakukan PJJ. Kurang dari $50 \%$ Waktu pembelajaran yang diberikan sesuai, peserta didik puas menerima waktu pembelajaran per hari, komunikasi mahasiswa dengan dosen pendidik klinis tergolong baik, serta pengaturan jadwal pembelajaran dengan dokter klinis cukup mudah. Responden menjawab PJJ cukup efektif sebanyak $56,86 \%$.
\end{abstract}


Kesimpulan: Permasalahan yang paling menonjol adalah pemenuhan kompetensi kepaniteraan klinis dalam interaksi dengan pasien di RS Pendidikan dikarenakan pandemi. Namun daripada itu, berbagai upaya telah dilakukan oleh Instansi penyelenggara pendidikan kedokteran klinis.

Kata kunci : Kepaniteraan Klinis - RS Pendidikan - Pembelajaran Jarak Jauh - Program Studi Profesi Dokter

\section{PENDAHULUAN}

Segala lini kehidupan kini terdampak adanyak virus Corona penyebab Covid-19, termasuk di Indonesia. Dalam pendidikan dan cara hidup masyarakat berubah, perubahan yang mencolok dari masyarakat yang menjalani kehidupannya serta proses belajar mengajar. Seluruh proses pembelajaran tersebut, dari sekolah dasar, menengah hingga universitas dilakukan dari rumah, secara work from home maupun school from home.

Surat Menteri Pendidikan dan Kebudayaan Republik Indonesia Nomor 36962/MPK.A/HK/2020 Tanggal 17 Maret 2020 tentang Pembelajaran secara Daring dan Bekerja dari Rumah dalam Rangka Pencegahan Penyebaran Covid-19 dan Surat Edaran Nomor 1 tahun 2020 dari Kementerian Pendidikan dan Kebudayaan

tentang pencegahan Covid-19 di Perguruan Tinggi, menyatakan bahwa penyelenggaraan Pembelajaran Jarak Jauh (PJJ) disesuaikan dengan kondisi Perguruan Tinggi dengan memberikan arahan kepada mahasiswa untuk melakukan pembelajaran dari rumah (school from home).

Pembelajaran secara jarak jauh menjadikan peserta didik harus belajar secara mandiri, dalam menemukan sumber pembelajaran lain yang sebagai penunjang, pembelajaran yang awalnya dilakukan melalui tatap muka di kelas, untuk saat ini dilakukan dengan jarak jauh.

Undang - undang Nomor 23 tahun 1992 tentang kesehatan menyebutkan rumah sakit sebagai salah satu sarana pelayanan kesehatan merupakan tempat bekerja pada tenaga profesional yang melakukan kegiatan berdasar sumpah dan etika profesi. Dokter adalah salah satu tenaga profesional yang sangat menentukan kualitas pelayanan kesehatan di rumah sakit.

Tahapan untuk menghasilkan seorang dokter profesional melalui tahapaan akademik yang dilalui dengan pendidikan di Fakultas Kedokteran dengan kelulusan bergelar Sarjana Kedokteran (S.Ked), tahap berikutnya adalah tahap pendidikan profesi yang dilakukan di Institusi Pelayanan Kesehatan yaitu di Rumah Sakit ataupun Puskesmas. Pendidikan kedokteran meliputi Pelatihan Keterampilan Klinik dan Non Klinik termasuk di dalamnya Praktik klinik (Clinical Practice) sesuai dengan prosedur medis yang berlaku di RS Pendidikan sesuai tingkat ketrampilan yang tercantum dalam Standar Kompetensi Dokter Indonesia.

Suatu hal yang tidak mudah dalam mengatur sistem kegiatan kepaniteraan klinik mahasiswa pendidikan profesi dokter pada saat melanjutkan stase di rumah sakit selama masa pandemi (Covid-19) sehingga peserta didik masih dapat mendapatkan pengetahuan dan keterampilan yang sesuai dengan kompetensi yang sudah ditetapkan.

Kegiatan kepaniteraan klinik yang dilaksanakan pada periode tersebut yang sebelum pandemi dilaksanakan secara tatap muka seperti journal reading, referat dan sejenisnya yang dapat diganti pelaksanaannya dengan memanfaatkan sistem dalam jaringan (daring) / online atau Pembelajaran Jarak Jauh (PJJ), tetapi kegiatan kepaniteraan klinik 
berupa praktik klinik/hands on di rumah sakit pendidikan, dan merupakan kegiatan lanjutan dari masing-masing siklus akan dilaksanakan setelah ada ketentuan selanjutnya dengan lama waktu pelaksanaan adalah selama 4 minggu untuk siklus kecil dan 8 minggu untuk siklus besar.

Penilaian terhadap dokter muda dilakukan sesuai dengan bentuk kegiatan secara daring yang telah dilaksanakan dengan mengacu pada sistem penilaian yang ada, sedangkan untuk nilai akhir diberikan setelah seluruh kegiatan kepaniteraan klinik baik secara daring maupun secara hands on diselesaikan.

\section{METODE PENELITIAN}

Penelitian deskriptif terhadap peserta didik kepaniteraan muda (koass) Fakultas Kedokteran Universitas Kristen Krida Wacana (UKRIDA) yang melakukan kegiatan daring selama masa pandemi Covid-19 di Rumah
Sakit Pendidikan. Peserta didik yang mengikuti kegiatan pembelajaran daring mengisi angket dari formulir elektrik berupa skala dan menjawab pendapatnya dengan jawaban singkat. Hasil dari pengisian formulir dianalisis secara deskriptif .

\section{HASIL DAN PEMBAHASAN}

Dari populasi target, terdapat 51 responden dengan karakteristik seperti pada tabel 1. Populasi terbanyak responden berusia 23-24 tahun (45,09\%), dan paling banyak dari mereka dalam pendidikan rotasi di RSUD Koja (68,62\%). Sebanyak 58,82 \% responden adalah perempuan, dan $84,31 \%$ responden lulus dari pendidikan akademik di tahun 20192020. Sebanyak $47,05 \%$ dari responden baru menjalankan stase (rotasi) sebanyak 1-2 rotasi. Lama menunggu pandemi 5-7 bulan di alami oleh $56,86 \%$ responden, dan sebanyak $74, \% \%$ responden masih menetap di Jakarta selama pandemic.

Tabel 1. Karakteristik Responden

\begin{tabular}{ll} 
Usia (tahun) & \\
\hline $21-22$ & $18(35,29 \%)$ \\
$23-24$ & $23(45,09 \%)$ \\
$25-26$ & $8(15,68 \%)$ \\
>26 & $2(3,9 \%)$ \\
RS Pendidikan & $35(68,62 \%)$ \\
\hline RSUD Koja & $3(5,8 \%)$ \\
RSAU Ernawan Antariksa & $5(9,81 \%)$ \\
RS Tarakan & $4(7,8 \%)$ \\
RS Jiwa Grogol & $1(1,96 \%)$ \\
Puskesmas & $1(1,96 \%)$ \\
Ukrida & $1(1,96 \%)$ \\
RSUD Cengkareng & $1(1,96 \%)$ \\
Lain lain & \\
Apakah saat ini melakukan pembelajaran jarak jauh & $36(70,58 \%)$ \\
\hline Ya & $15(29,41 \%)$ \\
tidak & \\
Jenis Kelamin & $21(41,17 \%)$ \\
\hline Laki-laki & $30(58,82 \%)$ \\
Perempuan & \\
Tahun lulus Sarjana Kedokteran $2015-2016$ & $5(9,8 \%)$ \\
$2017-2018$ & $3(15,68 \%)$ \\
$2019-2020$ & $43(84,31 \%)$ \\
Jumlah stase yang sudah dijalankan & \\
\hline O & $4(7,84 \%)$ \\
1-2 & $24(47,05 \%)$ \\
3-4 & $18(35,29 \%)$ \\
5-6 & $3(5,88 \%)$ \\
&
\end{tabular}


Lama menunggu pandemi

\begin{tabular}{ll}
\cline { 2 - 2 } <1 bln & $3(5,88 \%)$ \\
$2-4$ bulan & $7(13,72 \%)$ \\
$5-7$ bulan & $29(56,86 \%)$ \\
$>8$ bulan & $7(13,72 \%)$ \\
Domisili selama pandemi & \\
\hline Jakarta & $38(74,50 \%)$ \\
Wilayah Kalimantan & $5(9,8 \%)$ \\
Lain lain & $5(9,8 \%)$ \\
Semarang & $2(3,92 \%)$ \\
Wilayah Papua & $1(1,96 \%)$ \\
Akses Internet & \\
\hline Wifi & $36(70,58 \%)$ \\
Mobile data & $15(29,41 \%)$
\end{tabular}

Sebanyak $78,43 \%$ peserta didik tidak sebanyak $52,94 \%$ peserta didik beradaptasi mengalami kesulitan akses internet, dan cukup melakukan PJJ (Grafik 1 dan grafik 2).

\section{Kesulitan Akses Internet}

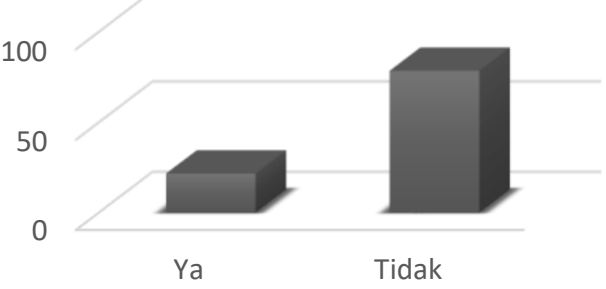

Grafik 1. Kesulitan peserta didik dalam mengakses Internet

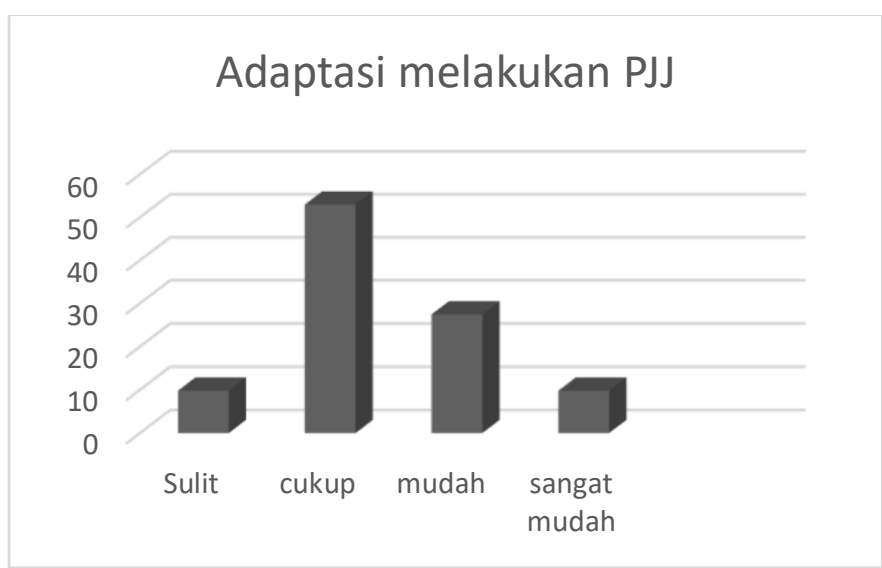

Grafik 2. Tingkat adaptasi PJJ

Waktu pembelajaran yang diberikan selama PJJ sesuai menurut $47,06 \%$ peserta didik, dan 49,02\% peserta didik puas menerima jumlah waktu pembelajaran yang diberikan selama PJJ, 56,86\% peserta didik puas menerima jumlah jam stand by (waktu pembelajaran) per hari selama PJJ (grafik 2,3 dan 4). 


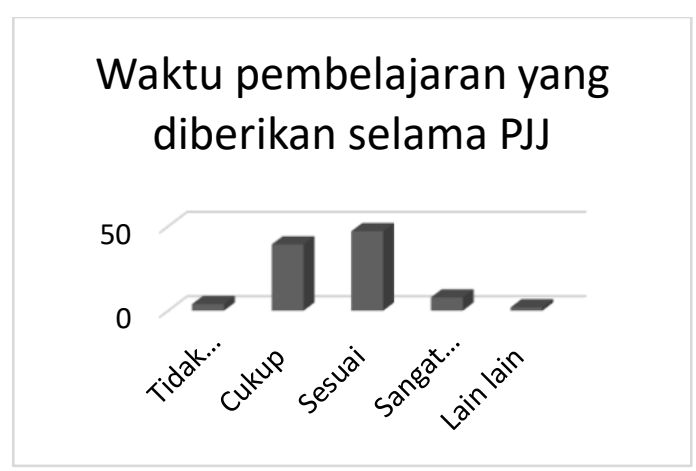

Grafik 3. Waktu pembelajaran yang diberikan selama PJJ.

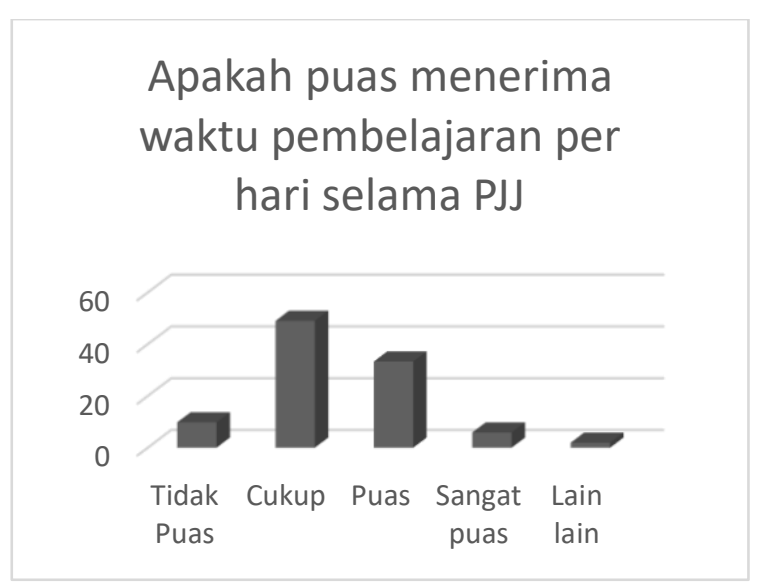

Grafik 4. Kepuasan menerima waktu pembelajaran per hari selama PJJ.

Komunikasi mahasiswa dengan dosen pendidik klinis

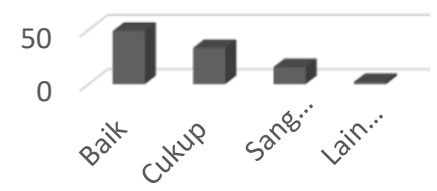

Grafik 5. Komunikasi peserta didik dengan dosen pendidik klinis

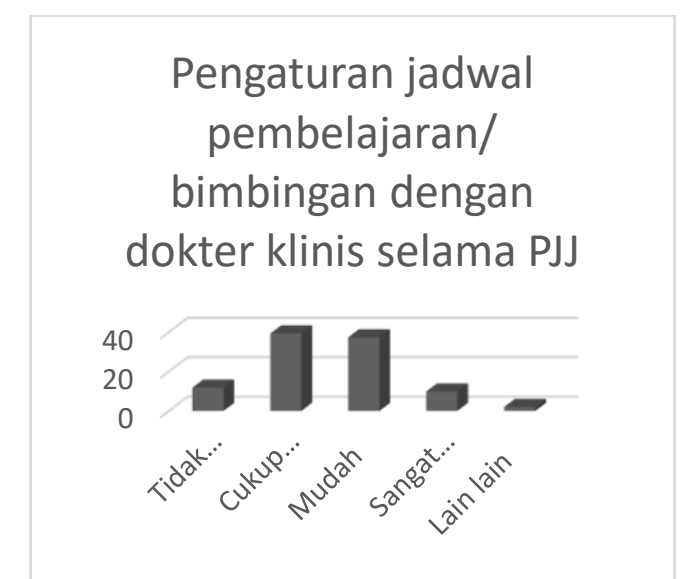

Grafik 6. Pengaturan jadwal pembelajaran/bimbingan dengan dokter klinis selama PJJ. 
Komunikasi mahasiswa dengan dosen pendidik klinis tergolong baik dari 49,02\% peserta didik. Sedangakan pengaturan jadwal pembelajaran/bimbingan dengan dokter klinis selama PJJ cukup mudah $(39,21 \%)$ (grafik 5 dan 6). Responden menjawab PJJ cukup efektif dalam PJJ sebenyak 56,86\% (grafik 7). Pandemi covid 19 di Indonesia saat ini sudah memasuki bulan ke- delapan, sangat berpengaruh terhadap aktivitas pembelajaran kepaniteraan klinis (koass) Fakultas Kedokteran Program Studi Pendidikan Profesi Dokter (PSPD). Peserta didik yang seharusnya menjalankan kegiatan di bagian tertentu di Rumah Sakit Pendidikan, seperti kehilangan arah

\section{Keefektifan Sistem PJJ efektif untuk pelaksanaan bimbingan kepaniteraan}

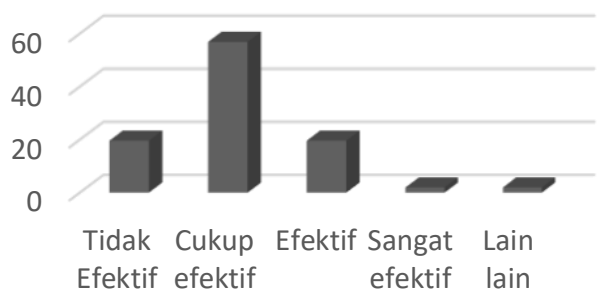

\section{Grafik 7. Keefektifan Sistem PJJ untuk pelaksanaan bimbingan kepaniteraan}

Jangka waktu pendidikan praktik klinis mayor (10 minggu) terdiri atas: Ilmu Penyakit Dalam, IImu Bedah, IImu Kesehatan Anak, IImu Kebidanan dan Kandungan (Obgyn), dan IImu Kesehatan Masyarakat. Sedangkan praktik klinis minor (2-5 minggu) terdiri atas: Neurologi, Kulit Kelamin, THT, Mata, Anestesi, Radiologi,
Jiwa dan Forensik. Jumlah dokter muda yang dapat diterima untuk melakukan praktik klinis sesuai dengan kapasitas KSM dengan syarat perbandingan pembimbing klinis : peserta didik tidak boleh melebihi $1: 5$ untuk rotasi mayor dan minor.

Tabel 1. Tahap pembelajaran kepaniteraan muda di RS Pendidikan.

\begin{tabular}{|c|c|c|c|c|}
\hline Kriteria & Tingkat 1 & Tingkat 2 & Tingkat 3 & Tingkat 4 \\
\hline \multirow[t]{4}{*}{$\begin{array}{c}\text { Tingkat } \\
\text { Keterampilan Klinis }\end{array}$} & & & & Mampu melakukan secara mandiri \\
\hline & & & \multicolumn{2}{|c|}{ Mampu Melakukan di bawah supervisi } \\
\hline & \multirow{2}{*}{\multicolumn{4}{|c|}{ Memahami Teori Keterampilan }} \\
\hline & & & & \\
\hline \multirow{4}{*}{$\begin{array}{l}\text { Metode Pembela } \\
\text { jaran }\end{array}$} & & & & Melakukan pada pasien \\
\hline & & & \multicolumn{2}{|c|}{ Berlatih alat peraga atau pasien } \\
\hline & & & servasi lan & emonstrasi \\
\hline & \multicolumn{4}{|r|}{ mandiri } \\
\hline
\end{tabular}




\begin{tabular}{|l|c|c|c|c|}
\hline Metode Penilaian & Ujian Tulis & $\begin{array}{c}\text { Penyelesaian kasus } \\
\text { secara tertulis dan / } \\
\text { atau lisan (oral test) }\end{array}$ & $\begin{array}{c}\text { Objective } \\
\text { Structured Clinical } \\
\text { Examination } \\
\text { (OSCE) }\end{array}$ & $\begin{array}{c}\text { Workbased Assesment seperti mini- } \\
\text { CEX, portofolio, logbook, dsb }\end{array}$ \\
\hline
\end{tabular}

Sumber : Buku Panduan Pelaksanaan Kepaniteraan Klinis IImu Penyakit Mata

Tahap pembelajaran kepaniteraan muda di RS Pendidikan meliputi tingkatan sebagai berikut : Tingkat kemampuan 1 (Knows) : mengetahui dan menjelaskan; Tingkat kemampuan 2 (Knows How): Pernah melihat atau didemonstrasikan; Tingkat kemampuan 3 (Shows) : Pernah melakukan atau pernah menerapkan di bawah supervisi; Tingkat kemampuan 4 (Does) : Mampu melakukan secara mandiri serta 4A. Keterampilan yang dicapai pada saat lulus dokter.

Materi pendidikan praktik klinis terdiri dari Bedsite Teaching, Case Base Discussion (CBD), Direct Observation of Procedural Skills (DOPS), Mini Clinical Evaluation (Mini CEX) dan Objective Structure Long Examination Record (OSLER) yang tidak dapat dilakukan secara daring. Adapun uraiannya adalah sebagai berikut : Bedsite teaching merupakan pengajaran berbasis pasien dimana peserta didik melihat dan mempelajati kasus secara langsung dalam mepraktekkan kemampuan klinisnya, dalam bentuk visite rawat inap. Case based discussion (CBD) dengan menggunakan metode tanya jawab dan diskusi terstruktur berdasarkan kasus untuk menilai kemampuan penalaran klinis (clinical reasoning) peserta didik, sehingga dapat memahami dasar/alasan dibalik sebuah keputusan.

\section{Direct Observation of Procedural Skills} (DOPS) merupakan metode penilaian yang difokuskan untuk menilai keterampilan prosedural peserta didik dengan cara mengobservasi mereka saat berinteraksi dengan pasien. Mini Clinical Evaluation Exercise (Mini-CEX) adalah metode yang dirancang untuk menilai ketrerampilan klinis esensial yang dibutuhkan dalam pelayanan klinis yang baik, meliputi perilaku, pengetahuan dan sikap. Objective Structure Long Examination Record (OSLER), yaitu modifikasi ujian klinis kasus panjang yang digunakan dalam pendidikan tahap profesi dokter (kepaniteraan klinis) untuk menilai kemampuan klinis peserta didik dalam menghadapi kasus tertentu secara komprehensif, terdiri dari 10 butir penilaian. Adapun butir penilaian tersebut meliputi : Anamnesis meliputi proses ketrampilan komunikasi, pendekatan sistematik, dan pendekatan fakta kasus, Pemeriksaan fisik, yaitu pendekatan sistematik, teknik pemeriksaan dan penegakan temuan fisik yang tepat, penilaian lainnya terdiri dari perencanaan pemeriksaan lanjutan yang rasional, manajemen tepat dan kecermatan klinis. ${ }^{1}$ Pengajaran yang dapat dilakukan secara daring hanya meliputi referat/ karya ilmiah, jurnal reading, pre tes dan post tes.

Ketika Flu Spanyol merebak di Indonesia pada Maret 1818 hingga September 1919, total kematian sekitar 1,3 juta atau 2,5 persen dari jumlah populasi Indonesia waktu itu yakni 53 juta orang, hal tersebut mempengaruhi pola pendidikan kedokteran di saat itu. Walaupun kala itu berbeda dengan sekarang dimana adanya kemajuan teknologi, pendidikan kedokteran di masa pandemi 
Covid-19 dapat dilaksanakan dalam bentuk Pendidikan Jarak Jauh (PJJ). Kita tidak bisa memungkiri, pemenuhan kompetensi menjadi lebih sulit.

Hingga saat ini belum ada penyelesaian masalah mengenai bagaimana menyelesaikan proses pembelajaran hands on di RS Pendidikan. Dengan memperpanjang durasi sepertinya adalah solusi ideal, tapi beban staf pendidik dan peserta didik akan bertambah. Konsekuensi, pertimbangan untung rugi dalam pengambilan keputusan harus diperhitungkan oleh para pembuat kebijakan pendidikan.

Integrasi IImu Kedokteran Dasar dan

IImu Kedokteran Klinis adalah integrasi Pendidikan berbasis kompetensi. Pengetahuan meliputi aspek kognitif melalui kuliah interaktif, pembelajran mandiri dan diskusi kelompok. Kemampuan peserta didik dalam melakukan prosedur klinis, ketepatan algortma diagnosis, tata laksana dan komunikasi merupakan aspek skill. Sedangkan empati dan etika merupakan aspek profesionalisme. ${ }^{2}$

Aspek mana sajakah yang sulit diterapkan pada pandemi sekarang ini ? Aspek ketrampilan membutuhkan supervisi langsung oleh dokter pendidik klinis untuk bisa dipastikan kompetensi peserta didik memang memenuhi syarat.

Di sisi aspek profesionalisme, peranan staf pengajar dan dokter pendidik klinis serta institusi pendidikan sangat penting yaitu role model, teladan yang baik bagi peserta didik. Evaluasi aspek profesionalisme juga menjadi sulit karena pembatasan sosial. Upaya-upaya yang dilakukan semisal pembuatan video percobaan untuk menunjang kegiatan praktikum peserta didik, rupanya belum dapat tergantikan pada era PJJ sekarang ini. Interaksi langsung dengan pasien di Rumah Sakit sebagai sumber dari data obyektif untuk menunjang ketrampilan klinis akan terhambat. Beberapa tindakan klinis memerlukan supervisi yang rinci dari dokter pendidik klinis, yang dalam hal ini tidak dapat tergantikan dengan metode PJJ. Penelitian membuktikan bahwa capaian akhir dan nilai kepuasan peserta didik lebih rendah pada diskusi simulasi daripada diskusi langsung. ${ }^{3,4}$

Perubahan metode pendidikan kedokteran pada era pandemi dengan PJJ adalah sebuah tantangan baru. Aspek aspek keterampilan klinis, pengalaman dengan pasien dan aspek profesionalisme belum dapat tergantikan dengan metode PJJ. ${ }^{5}$

Metode evaluasi dan ujian klinis berbasis pasien juga menjadi sulit dilaksanakan mengingat adanya pembatasan sosial. Hal itu menunjukkan bahwa selain munculnya kesulitan dalam mencapai standar kompetensi dokter Indonesia, metode evaluasi untuk menilai tercapainya kompetensi tersebut juga masih menjadi kendala.

Memang berbeda metode pembelajaran sebelum masa pandemi, dengan segala keterbatasan saat ini, metode PJJ dinilai belum efektif dalam mencapai tujuan pendidikan kedokteran, lulusan dokter berpotensi sulit penilaian obyektifnya ketika ukurannya menggunakan metode sebelum pandemi. Lulusan dokter yang menjalani pendidikan kedokteran saat pandemi juga berpotensi terancam secara profesionalisme.

Pada konteks pandemi Covid-19, kebijakan pembatasan sosial dan fisik merupakan hal yang sangat penting dalam memutus rantai penularan. Dengan demikian, apabila pendidikan kedokteran tetap dilaksanakan secara tatap muka, 
meningkatkan kemungkinan bahwa peserta didik klinis yang menjalani praktik klinik dapat secara tidak disadari menularkan Covid-19 kepada pasien yang diperiksa, atau sebaliknya. $^{5}$

Beberapa penelitian menyebutkan bahwa peserta didik kepaniteraan bukanlah pekerja esensial, karenanya seharusnya tidak terlibat dalam perawatan pasien langsung. Wawancara secara Semi-terstruktur dengan mahasiswa kedokteran yang sedang menangani pasien yang terinfeksi oleh Tabari et al, menunjukkan bahwa banyak dari mereka tidak siap untuk menghadapinya masalah tak terduga selama layanan mereka belajar. Ini termasuk tekanan psikologis, krisis manajemen, dan masalah pendidikan kesehatan masyarakat. ${ }^{6}$

Beberapa Fakultas Kedokteran di negara lain, di Amerika dan Eropa mengubah sistem pendidikan agar peserta didik dapat lulus lebih cepat, sehingga dapat turut menangani pandemi COVID-19. Begitu halnya saat pandemi Flu Spanyol juga terjadi hal serupa. $7,8,9$

Terdapat pilihan dalam menghadapi permasalahan mengenai Kepaniteraan Klinis selama masa pandemi ini, bertahan menunggu pandemi selesai atau mempercepat kelulusan dokter.

Dengan mempercepat kelulusan dokter, maka titik berat pada fokus penanganan kasus pandemi, tapi apakah ini akan berhasil ? ternyata banyak peserta didik yang baru saja menyelesaikan sarjana kedokteran, dalam hal ini, mereka masih belum dibekali skill klinis, memang yang sudah menyelesaikan rotasi/stase terakhir juga tidak kalah banyak, bahkan yang menunggu UKDI juga jumlahnya tidak sedikit. Dengan demikian, penentu kebijakan di negeri ini memang di tuntut mengambil keputusan dengan mempertimbangan risk dan benefit nya, atau perlu dipikirkan kebijakan-kebijakannya misalnya yang hampir lulus atau sedang menunggu UKDI, kiranya diperlancar prosesnya, mereka sebenarnya sudah menyelesaikan semua proses, hanya proses administrasinya yang belum selesai. Untuk yang baru lulus akademis (S.Ked) mau tidak mau memang harus berproses menunggu pandemi berakhir dengan memperbanyak daring (mulai mengikuti mengerjakan referat, jurnal reading, pre tes) serta kegiatan yang masih bisa dilakukan dengan daring.

Dari pengamatan di lapangan, memang terjadi perubahan-perubahan kebijakan lokal seiring naik turunnya angka penderita Covid-19. Di awal pandemi, masih dilakukan kepaniteraan klinis secara hands on dengan protokol kesehatan yang ketat, namun hal ini tidak berlangsung lama, peserta didik yang sedang melaksanakan hands on tiba tiba berhenti dikarenakan angka penderita Covid19 yang naik. Memang ini menjadi pemikiran untuk kita semua, untuk pendidik, untuk Instansi Rumah Sakit Pendidikan, serta Fakultas Kedokteran penyelenggara Profesi Dokter.

Untuk kepaniteraan muda, PJJ memang menghilangkan hubungan pasiendokter, namun tampaknya untuk saat ini menjadi satu-satunya pilihan. Berharap semua pihak untuk terus mengevaluasi, meninjau, dan meningkatkan upaya melanjutkan pendidikan kedokteran, terutama selama pandemi ini, serta perlunya mengembangkan pengujian dan standar protokol kepaniteraan. Penelitian lebih lanjut diperlukan dalam mengevaluasi PJJ dan menemukan metode yang terbaik dalam 
pendidikan kedokteran pada umumnya dan pendidikan kepaniteraan pada khususnya. ${ }^{7,10}$

\section{KESIMPULAN DAN SARAN}

Permasalahan yang paling menonjol adalah pemenuhan kompetensi kepaniteraan klinis dalam interaksi dengan pasien di RS Pendidikan dikarenakan pandemi. Namun daripada itu, berbagai upaya telah dilakukan oleh Instansi penyelenggara pendidikan kedokteran klinis, oleh karena itu perlu adanya kebijakan yang tepat, cepat dengan mempertimbangan segala aspek.

\section{UCAPAN TERIMA KASIH}

Ucapan terima kasih ditujukan kepada Prof. Dr Unifah R, M.Pd, Prof Dr Suparno Eko W, MM, Dr M. Sofwan effendi, M. Ed, Dekan FKIK UKRIDA, Direktur RS Pendidikan Utama dan Satelit, Bagian Diklat RSUD Koja, serta seluruh peserta didik kepaniteraan klinis yang sudah menjadi responden.

\section{Konflik Kepentingan}

Tidak ada konflik kepentingan.

\section{REFERENSI}

1. 1.Buku Panduan Pelaksanaan Kepaniteraan Klinis IImu Penyakit Mata, Rumah Sakit Umum Daerah Koja, Program Studi Pendidikan Profesi Dokter (PSPPD) FKIK UKRIDA, 2020.

2. 2.Konsorsium IImu Kesehatan. Perkembangan pendidikan kedokteran di Indonesia: Sistem Pendidikan Kedokteran di Indonesia menuju 2045. 1st ed. Indonesia: Konsorsium IImu Kesehatan; 2013.

3. Couto T, Farhat S, Geis G, Olsen O, Schvartsman C. High-fidelity simulation versus case-based discussion for teaching medical students in Brazil about pediatric emergencies. Clinics. 2015;70(6):393-399.

4. Bokken L, Rethans J, Scherpbier A, van der Vleuten C. Strengths and Weaknesses of Simulated and Real Patients in the Teaching of Skills to Medical Students: A Review. Simulation in Healthcare: The Journal of the Society for Simulation in Healthcare. 2008;3(3):161-169.

5. Rozaliyani A, Widjaja HT, Prawiroharjo $P$, dan Sukarya W. Kajian Etik Pendidikan Jarak Jauh dalam Pendidikan Kedokteran di Indonesia Jurnal Etika Kedokteran Indonesia Vol 4 No. 2 Sep 2020.

6. Tabari, P, Amini, M, \& Moosavi, M. Lesson learned from COVID-19 epidemic in Iran: The role of medical

7. education. In Medical Teacher. 2020, VOL. 42, NO. 7 , 833-841. https://doi.org/10.1080/0142159X.2020.1754376

8. Rose S. Medical Student Education in the Time of COVID-19. JAMA. 2020;323(21):2131-2132. doi:10.1001/ jama.2020.5227 available from: https:// jamanetwork.com/journals/jama/ fullarticle/2764138.

9. Miller DG, Pierson L, Doernberg S. The Role of Medical Students During the COVID-19 Pandemic. Ann Intern Med. 2020 Jul 21;173(2):145-146. doi: 10.7326/M20-1281. Epub 2020 Apr 7. PMID: 32259194; PMCID: PMC7151405.

10. Prescott JE. Important Guidance for Medical Students on Clinical Rotations During the Coronavirus (COVID19) Outbreak / AAMC [Internet]. 2020 [cited 2020 Jun 20]. Available from: https://www. aamc.org/newsinsights/press-releases/ important-guidance-medical-studentsclinical-rotations-during-coronavirus-covid19outbreak.

11. Kelly, K, Hwei, LRY, \& Octavius, GS, Coronavirus outbreaks including COVID-19 and impacts on medical education: a systematic review. Journal of Community Empowerment for Health. Vol 3 (2) 2020, 130-140 . DOI: 10.22146/jcoemph.57082 